\title{
Research on the Historical Process and Value Orientation of Teacher Education Cooperation Among Guangdong, Hong Kong and Macao
}

\author{
Jiao Zeng ${ }^{1, *}$ \\ ${ }^{1}$ South China Business College, Guangdong University of Foreign Studies, Guangzhou, Guangdong 510545, \\ China \\ *Corresponding author. Email: zengjiao1234@163.com
}

\begin{abstract}
Teacher education in Guangdong, Hong Kong and Macao has both similarities and differences. The cooperation of teacher education in Guangdong, Hong Kong and Macao has gone through three stages: "one-way output" stage, "multi-directional interaction" stage and "win-win integration" stage. Throughout the process of teacher education cooperation among Guangdong, Hong Kong and Macao, its value orientation is constantly changing. Since Hong Kong's and Macao's return to China, strengthening their national identity concept has always been the political orientation of the policy and practice adjustment of teacher education cooperation among the three places; the construction of Guangdong-Hong Kong-Macao Greater Bay Area (GBA) has risen to a national strategic period, and serving GBA has become the value orientation of the policy and practice adjustment of teacher education cooperation; in the educational practice of GBA, the mutual recognition of teacher qualification standards has become the tool orientation of teacher education cooperation policy and practice. In the future, the teacher education cooperation among Guangdong, Hong Kong and Macao should take the construction of GBA as an opportunity to quickly integrate into the overall situation of national development under the framework of "one country, two systems", so that the teacher education cooperation between Guangdong, Hong Kong and Macao can develop into a community with a shared future.
\end{abstract}

Keywords: Guangdong-Hong Kong-Macao Greater Bay Area (GBA), Teacher education, Value orientation.

\section{INTRODUCTION}

Teacher education is becoming the key to school reform and even the sustainable development of education. With the in-depth development of the construction of GuangdongHong Kong-Macao Greater Bay Area (GBA), teacher education cooperation not only serves the internal education development of the three areas, but also gradually plays an important role in the overall construction of the GBA. GBA includes Kong Special Administrative Region, Macao Special Administrative Region and nine cities of Guangdong province, covering an area of 56,000

*Sponsors: Philosophy and social science planning project of Guangdong Province: Research on the integrated development of GBA preschool teacher education. Approval No.: GD18XJY13 square kilometers. With a total population of about $8,617,000$ in 2020 , GBA is one of the regions with the highest degree of openness and the strongest economic vitality in China, and plays an important strategic role in the overall situation of national development. In recent years, the cooperation in teacher education in GBA has been deepened. In 2018, the Faculty Education College of GBA has been established, and the GBA teachers' Federation was established in 2019. The importance of teacher education cooperation in the construction of GBA has been emphasized and practiced. 


\section{HISTORICAL PROCESS OF TEACHER EDUCATION COOPERATION AMONG GUANGDONG, HONG KONG AND MACAO}

Almost all over the world, teacher training has been a neglected topic before modern times.[1] Even at the end of the 20th century, this still became a normal phenomenon in some countries or regions. For example, UNESCO once reported that in Uruguay in the 1990s, $70 \%$ of secondary school teachers were untrained; In Togo, $84 \%$ of junior high school teachers are untrained. Even in the United States, more than $12 \%$ of new teachers come into the classroom without any formal training, and the other $14 \%$ of new teachers do not fully meet the national standards.[2] The nature of teacher education in the governed places all over the world is deeply influenced by the model of the country of control,[3] and so are Hong Kong and Macao. In the course of teacher education cooperation in Guangdong, Hong Kong and Macao, there are different cooperative paths in different periods. The driving force of path turning is the development of politics, economy, culture and education itself.

\subsection{One Way Output Stage: 1970s to the End of the 20th Century}

Before the reunification, many teachers in Hong Kong and Macao were untrained. The Macao Portuguese government's laissez faire policy towards private schools lasted until the 1980s. The government sponsored teacher education, like other education and training fields, benefited less than the vast number of private schools. Before the 20th century, the Hong Kong British government was not willing to take more responsibility in teacher education except for minimal efforts. However, with the development of social economy and the increase of population, in order to respond to the actual needs, the ruling authorities began to develop education, cultivate talents, and then began to train teachers. In the late 19th century and early 20th century, the development of Teacher Education in Hong Kong was very slow. It was not until the middle of the 20th century that a relatively complete teacher education system was basically formed, and more attention was paid to teachers' inservice training. On the eve of the reunification, although there are many shortcomings, teacher education in Hong Kong has made great progress and formed its own school running mode and characteristics.[4] The earliest normal school in mainland China can be traced back to the Capital University in 1898, in which the normal school was established in 1902, which became the predecessor of Beijing Normal University. After the founding of the People's Republic of China, in the national adjustment of colleges and departments, it is clear that the task of normal universities is to train teachers. So far, the traditional "three-level normal education system" has been formed.[5] However, it was not until the reform and opening-up that the normal education system began to develop greatly.

There is a big gap in the development of teacher education among the three regions, especially in Macao. Therefore, before the reunification, the main state of teacher education cooperation among the three places was a large number of one-way exports from Guangdong to Macao, sporadic exports to Hong Kong, and Hong Kong's complementary exports of teacher education resources to Macao. During the ten years from 1984 to 1994, Guangdong normal universities run schools in Hong Kong and Macao. They adopted the way of "going out" and sent teachers to teach in Hong Kong and Macao, including more than 1800 students of various levels and majors.[6] In October 1984, Guangdong Normal University opened a correspondence course in Hong Kong for Chinese, geography and mathematics. South China Normal University enrolled 41 students in that year. In addition, private schools in Macao, which adopt English education system, learn more from the experience of Hong Kong and Taiwan in terms of teaching materials and curriculum contents, and their teachers are trained more in Hong Kong than in Guangdong. However, as a whole, the number of teachers in Macao receiving educational resources from Guangdong is the largest.

\subsection{The Stage of Multi Direction Interaction: The Beginning of the 21st Century - the Middle of the 2010S}

Hong Kong returned to the motherland in 1997 and Macao returned to the motherland in 1999. The Chinese government resumed the exercise of sovereignty over the two special administrative regions and implemented the policies of "one country, two systems", "Hong Kong people ruling Hong Kong", "Macao people ruling Macao" and "a high degree of autonomy". This provides a strong political system guarantee for optimizing the allocation of educational resources, promoting 
educational equity, carrying out educational governance, improving the quality of education, and improving the status and treatment of teachers. When the basic law of Macao clarifies the fundamental policy of governing Macao, it also makes provisions on Macao's education, which provides a good legal basis for the development of Macao's education and normal education. Hong Kong is basically the same, both of them have the freedom to make their own education policies, education is independent, and education authority is relatively independent. The return of Hong Kong and Macao has brought unlimited opportunities for their education. Education serves the regional economic and social development, gradually eliminates the influence of colonial rule, and trains new talents to adapt to the changes of the new social and political situation.

After the return of Macao, higher education has experienced three stages: scale expansion stage, reform and transformation stage and quality improvement stage.[7] By means of new construction, upgrading and renaming, Macao's higher education has rapidly completed scale expansion, and the number of higher education institutions has increased to 10 (including 4 public universities and 6 private universities), forming a diversified higher education pattern with public as the main and private as the auxiliary. The government of Macao Special Administrative Region has given more responsibilities of teacher education to local universities. After 2003, the MSAR government approved 53 teacher education courses in the University of Macao, including diploma courses, bachelor's degree courses, master's degree courses and doctor's degree courses, covering all aspects of teacher education, such as curriculum and teaching, pre-school education, primary school education, physical education and so on. In addition, the University of science and technology of Macao, City University of Macao, Saint Joseph University and Macao Polytechnic University are approved to offer teacher education courses at the level of bachelor's degree or above.[8] There are few related courses co organized with universities outside Macao. The transformation of Macao's teacher education from relying on foreign aid to self-reliance has been realized. Hong Kong, on the other hand, takes developed countries or regions rather than the mainland as its reference. The "Education Commission Report No. 7" issued in 1997 puts forward opinions and suggestions on the direction and focus of Hong Kong's education reform and development at the time of reunification, as well as on the development of world education and Hong Kong's social needs. It clearly positions Hong Kong in the international coordinate of education, including international education concepts such as teacher education, which has become an important reference for Hong Kong's education and teacher development.[9] As Bei Lei and Gu Dingyi have said, "Hong Kong has very little innovation in the field of education that draws lessons from Chinese speaking regions... Educators and policy makers in Hong Kong have contacts with the mainland and Taiwan, but they often feel that they can learn little from these two regions, so they tend to introduce innovative content from Australia, Canada, the British Commonwealth and the United States."[10]

Under the new political, economic and educational development background, the teacher education exchange and cooperation among Guangdong, Hong Kong and Macao has changed from one-way input to multi-way interaction. The higher education and teacher education in the three places have their own advantages and characteristics, and the mode of cooperation and complementarity has replaced the mode of aid. According to the statistics of Macao Education and Youth Development Bureau, 43.3\% of Macao students went to other places to study in 2012-2013 academic year, $45.2 \%$ in 2015-2016 academic year, and $52 \%$ in 2018-2019 academic year; ${ }^{1}$ With the development of the mainland economy, the improvement of the reputation of higher education and the increase of the number of "recommended students" in Macao. The mainland has become the largest destination for the outflow of high school graduates from Macao. Taking the data of 20182019 academic year as an example, $30.9 \%$ of the total number of high school graduates in Macao were promoted to mainland universities; The second is Taiwan, accounting for $10.6 \%$, and the third is Hong Kong, accounting for $1.3 \%$. The number of provinces and cities in which Macao's colleges and universities recruit students from the mainland is also expanding, from 17 provinces, cities and autonomous regions in 2005 to 25 in 2009. The number of mainland students in Macao's universities has increased from 5653 before the handover to 17992 in $2019 .^{2}$ According to the data of the Ministry of education of the People's

1. Data from Macao Higher Education Bureau: https://www.dses.gov.mo/about/depart/intro.

2. Data from Macao Education and Youth Bureau: https://portal.dsej.gov.mo/webdsejspace/internet/Inter_main_pag e.jsp?id=8493. 
Republic of China, as of July 2020, 380 mainland (mainland) universities have the qualifications to recruit students from Hong Kong, Macao and Taiwan, and 16200 Hong Kong students are studying in mainland universities. In 2012, 63 mainland universities participated in the scheme, and then the number of mainland universities joining the scheme increased year by year. As of October 2019, a total of 122 Mainland Colleges and universities are eligible for the Hong Kong Diploma of secondary education examination.

\subsection{Integration and Win-Win Stage: from Mid-2010 to Now}

Since the reform and opening up, although the teacher education cooperation among Guangdong, Hong Kong and Macao has made a lot of achievements and experience, it is still selfcontained and relatively scattered. The teacher education cooperation among Guangdong, Hong Kong and Macao, facing the world as a whole and participating in the reform and development of teacher education together, is gradually formed after upgrading from GBA to the national strategy.[9]

GBA has lasted more than 20 years from academic discussion to local policy consideration, and then to the national strategy. "The 13th five year plan for national economic and social development of the People's Republic of China" issued in March 2016 clearly stated that "we should support Hong Kong and Macao to play an important role in regional cooperation in the Pearl River Delta, and promote GBA and major cross provincial cooperation platforms."[11] It opens up strategic planning at the national level. By February 18, 2019, the CPC Central Committee and the State Council have issued the outline of GBA development plan, which has defined the five strategic orientations of GBA: first, it is a worldclass urban agglomeration full of vitality; second, it is a world-class urban agglomeration full of vitality; Second, it is an international science and technology innovation center with global influence; Third, it is one of the important supports one belt, one road construction. Fourth, it is a demonstration zone for in-depth cooperation between the mainland and Hong Kong and Macao; fifthly, it is a quality life circle suitable for living, working and traveling. The teacher education cooperation of Guangdong, Hong Kong and Macao began to develop in a win-win way under the new strategic framework. The development process and level of teacher education in Guangdong, Hong Kong and Macao are different, but they all present the overall trend of modern teacher education: from single and closed to comprehensive and open.

The report of the 19th National Congress of the Communist Party of China clearly pointed out that we should "develop and strengthen the power of loving the motherland, Hong Kong and Macao, enhance the national consciousness and patriotism of our compatriots in Hong Kong and Macao, and let our compatriots in Hong Kong and Macao share the historical responsibility of national rejuvenation and the great glory of prosperity and strength of our motherland with the people of our motherland." With the acceleration of GBA construction, more and more people from Hong Kong and Macao come to GBA for entrepreneurship, employment and life. Chinese culture has always attached great importance to the education and cultivation of future generations. Whether children can be placed around to receive satisfactory education directly affects the "sense of security" and "sense of belonging" of people from Hong Kong and Macao. Therefore, the "GBA development plan outline" proposes "the construction of Hong Kong and Macao children's schools or the establishment of Hong Kong and Macao children's classes in Guangdong." In response to the needs of the new situation, Guangzhou has actively provided highquality and diversified basic education services for school-age children and adolescents of Hong Kong and Macao. Since 2019, pilot classes for children of Hong Kong and Macao have been set up. As of March 2021, 25 "Hong Kong and Macao children's classes" have been set up in nine schools in Guangzhou, with about 18000 students from Hong Kong, Macao and Taiwan studying in the basic education stage of Guangzhou.[12]

The school for children of Hong Kong and Macao is the benchmark of the basic education cooperation between Guangdong, Hong Kong and Macao, the base of patriotic education for teenagers in Hong Kong and Macao, and the cradle of GBA talent training. New schools in the new era call for new teachers. Therefore, in terms of teacher education cooperation, Guangdong, Hong Kong and Macao should focus on long-term development, integrated development, respond to the needs of the times, endow GBA with new connotation, new characteristics and cultivate new teachers in the new era. In early 2019, the Ministry of education of the People's Republic of China issued a notice saying that according to the principle of voluntariness, eligible residents of Hong Kong, 
Macao and Taiwan can apply for the mainland primary and secondary school teacher qualification examination to identify primary and secondary school teachers.

\section{AN ANALYSIS OF THE CHANGING ORIENTATION OF TEACHER EDUCATION COOPERATION AMONG GUANGDONG, HONG KONG AND MACAO}

The teacher education cooperation among Guangdong, Hong Kong and Macao has made some achievements and experience, and has formed its own framework and measures, but this does not mean that the education cooperation among the three places has been shaped or solidified. Throughout the process of teacher education cooperation among Guangdong, Hong Kong and Macao and the progress of GBA construction, the changes of various factors at home and abroad will put forward new requirements for teacher education cooperation, and the policies and practices of teacher education cooperation will continue to adjust and change.

\subsection{Strengthening National Identity Becomes the Political Orientation of Policy and Practice Adjustment of Teacher Education Cooperation}

There are three definitions of national identity in academic circles: first, from the perspective of the subject of national identity, national identity includes two levels: individual and state; Second, it defines from the functional dimension of national identity; Third, from the content dimension of national identity.[13] Previous studies have conducted a follow-up analysis on the national identity of adolescents in Macao and Hong Kong. The overall conclusion is that the national identity of adolescents in Macao is higher than that in Hong Kong, but there are still some disputes about the national identity of adolescents in Hong Kong. Some studies believe that although the national identity of Hong Kong youth has improved after the reunification, it is still relatively weak. At present, the national identity of Hong Kong Youth is not optimistic.[14][15][16] However, some studies have made different judgments. They think that Hong Kong people's recognition of region is higher than that of China, but they pay more and more attention to China's national identity.[17] Although the degree of national identity of Macao Youth is higher than that of Hong Kong, some studies have pointed out that in recent years, Macao Youth's political participation has shown some new characteristics, such as significantly enhanced awareness of political participation, deepening political participation, and certain crisis of political identity.[18]

National identity is an important means to maintain the existence and development of a nation-state. It is also the basis of integrating social resources, maintaining social stability and realizing long-term stability of a country. Due to the special historical reasons of Hong Kong and Macao and the influence of new international political forms, strengthening the education of national identity of Hong Kong and Macao teenagers is an important part of the success of "one country, two systems" in China. In the face of these problems, researchers also put forward different strategies. Some researchers explore the way to build the national identity of the young generation of Hong Kong from the aspects of giving full play to the positive guiding role of national education, promoting cultural communication and integration between Hong Kong and mainland of China, and building a positive image of the country through the media.[17] Other researchers analyze the imbalance between local identity and national identity from the perspective of economic interest relationship, and propose to solve the problems by developing Hong Kong's economy, solving people's livelihood problems, eliminating Hong Kong people's sense of relative deprivation, and cultivating common interest identity between the two places.[19]

School education is an important position to cultivate the national identity of Hong Kong and Macao teenagers, among which teachers are the most important key link. The function of teachers is to "preach, teach and solve doubts". Teachers not only teach students knowledge and skills, but also influence students' world outlook, outlook on life and values with their own thoughts and behaviors. They are the leaders of students' thoughts. Teachers' national identity attitude directly affects students' national identity. If a Hong Kong and Macao teacher highly identifies with his Chinese identity and has deep feelings for the motherland, even if there is no textbook of patriotism education, he will unconsciously infiltrate this kind of patriotism into the classroom, and imperceptibly affect the students' sense of national identity. On the contrary, if teachers themselves do not have a high sense of national identity, it will bring negative national 
image to students, and form resistance or even reverse thrust to teenagers' national identity. Therefore, we should attach great importance to the cultivation of national identity emotion in the teacher education cooperation among Guangdong, Hong Kong and Macao, which is an important political mission of teacher education. Whether it is the pre service training of teachers or the training of in-service teachers, it is necessary to add the element of national identity, even as a necessary index for the issuance of teacher qualification certificates and the assessment of in-service teachers. The exchange and cooperation of teacher education in Guangdong, Hong Kong and Macao must be based on the political orientation of promoting the integration of Hong Kong and Macao teenagers into the overall situation of national development and cultivating deep national identity.

\subsection{Serving GBA Has Become the Value Orientation of Policy and Practice Adjustment of Teacher Education Cooperation}

GBA construction is a major national strategy in the new era, in which education has a very important and special mission and role. Teacher education is the working machine of education and the power source to improve the quality of education. In the part of "building education and talent highland", "the outline of GBA development plan" puts forward "promoting the cooperative development of education", which not only orients the GBA education construction on the road of "cooperative development", but also sets the tone for the educational relations among Guangdong, Hong Kong and Macao. The same is true of the teacher education cooperation among Guangdong, Hong Kong and Macao. We must take the road of cooperation to serve the high-quality development of GBA education and the construction of GBA. In addition to the mutual enrollment of Higher Education (including normal universities) in Guangdong, Hong Kong and Macao for pre-service teacher education and training, post-service training and development are also the main contents of cooperation. The Ministry of education of China actively promotes academic communication among teachers and normal majors in Guangdong, Hong Kong and Macao. Through the "sister schools" platform, primary and secondary school teachers in the mainland and Hong Kong and Macao have extensively carried out communication activities such as job rotation teaching, teacher training, teaching research, and textbook compilation, so as to promote in-depth exchange and interaction among in-service teachers in the three places. Through the "teacher student exchange program between Hong Kong, Macao and mainland universities", we support and encourage normal universities to carry out study exchange programs. By building a number of brand activities such as the Guangdong-Hong Kong Language (English, Putonghua) teacher training project, the Guangdong-Hong Kong-Macao primary and secondary school principals forum, and the Shenzhen-Hong Kong principals forum, Guangdong Province, relying on GBA teachers' Education Institute, GBA teachers' Federation and other principals and teachers' exchange platforms, vigorously promotes a wider range of principals and teachers' professional exchanges, and promotes teachers' exchange, information sharing, and cooperation among Guangdong, Hong Kong and Macao Professional promotion and common development. Although it is not easy for the staff of Guangdong, Hong Kong and Macao to teach in other places, it will also be the reference direction for the government to formulate future policies. The teacher education cooperation among Guangdong, Hong Kong and Macao will serve the construction of GBA, which is its important mission at present and the direction for a long period of time.

\subsection{Mutual Recognition of Teacher Qualification Standards Has Become the Tool Orientation of Teacher Education Cooperation Policy and Practice}

The teacher qualification system is a statutory professional licensing system for teachers. It is the most basic requirement of a country or a region for those who are specialized in education and teaching. It is also an important means to promote the professional development of teachers. Since the 1960s, the Western Developed Countries have raised the tide of teacher professionalization, and the establishment of teacher qualification system has become the trend of the development of teacher education in the world. The mainland of China began to establish the teacher qualification system in the late 1980s, and began to implement it in 2001.[20] The current teacher qualification in Hong Kong is divided into two levels: certified teacher and permitted teacher. The former is registered on the premise that it has the teaching qualification 
under the Education Ordinance, that is, it has a teacher's certificate or degree teacher's Education Diploma in Hong Kong and is a permanent resident (or valid work visa) in Hong Kong. The latter holds only a diploma but does not receive teacher training and has teaching qualification. Permitted teacher can only be employed in schools specified in the permit. From the perspective of the way to obtain teacher qualification, the application for teacher qualification in Hong Kong can be roughly divided into two categories: first, graduates from teacher education institutions with professional qualification certification can obtain a bachelor's degree in education upon completion of credits; at the same time, they can also apply for registration as certified teachers with the qualification of Teacher Diploma; Second, graduates from a comprehensive university who have a bachelor's degree in non-education major and are willing to engage in education work need to register as a permitted teacher and study full-time for one year, or enter an employment school to study in-service for two years in a degree teacher education certificate or education diploma course. After obtaining the education certificate or diploma, they can apply for registration as certified teachers.[21] Due to historical reasons, the professionalization of teachers in Macao before the return of China was very low, which could not be compared with that of Guangdong and Hong Kong. After the handover, the Macao SAR government promulgated Law No. 9 / 2006 "outline law of non-higher education system", which made it clear for the first time that "professional development is the right and obligation of teaching staff".[22] On March 15, 2012, Law No. 3 / 2012 "framework of teaching staff system in non-higher education private schools" was passed, which provides legal protection for the majority of private school teachers in Macao to enjoy their due rights and puts forward new requirements for teachers' professional qualifications. The expectation of teachers' professional standards from all walks of life has also been greatly improved.

Although the standards and process of teacher qualification in Guangdong, Hong Kong and Macao are different, there are more and more similarities. This is not only the result of the development of teacher education in the world and the influence of teacher qualification certificate system, but also the development basis and advantages of mutual recognition of teacher qualification in Guangdong, Hong Kong and Macao. As Hong Kong and Macao have great autonomy in education, mutual recognition involves Hong Kong's consent to mainland teachers to teach in Hong Kong. At present, there are no conditions for the introduction of the policy of mutual recognition of teachers' qualifications in Guangdong, Hong Kong and Macao. However, the central government's Guiding Measures of mutual recognition and exchange are constantly being implemented.[23] Since 2019, the Ministry of education of China and the people's Government of Guangdong Province have jointly held a conference on promoting the development of GBA education cooperation. A series of documents have been issued to increase the supply of GBA basic education degrees, promote the enrollment of Hong Kong and Macao students in GBA basic education schools, support the construction of schools for children of Hong Kong and Macao, Hong Kong and Macao's educational system and mutual recognition of Curriculum. In order to promote the high-quality development of GBA basic education, top-level design and policy guarantee should be done well. In January 2019, the Ministry of education of the PRC issued the "notice on issues related to the application of Hong Kong, Macao and Taiwan compatriots for primary and secondary school teacher qualification certificates in the mainland ", allowing Hong Kong, Macao and Taiwan compatriots studying, working and living in the mainland to apply for primary and secondary school teacher qualification examination, and those who meet the conditions can be recognized as primary and secondary school teacher qualification. This policy is welcomed by residents of Hong Kong, Macao and Taiwan. According to statistics, in 2019, more than 800 relevant residents applied for the primary and secondary school teacher qualification examination. In order to further support Guangdong, Hong Kong and Macao residents to teach in GBA mainland primary and secondary schools, in November 2019, Guangdong Province continued to promote GBA professional qualification recognition in various fields to promote the convenient practice of Hong Kong and Macao talents in GBA mainland, including the promotion of primary and secondary school teacher qualification recognition of Hong Kong and Macao residents.

\section{CONCLUSION}

GBA's teacher education cooperation has changed from one-way assistance to multi-way interaction and then to win-win integration. The level and form of cooperation in each stage are greatly related to the development level of teacher 
education in Guangdong, Hong Kong and Macao, as well as the political, economic and other environmental factors among the three places. In the past, teacher education cooperation was mainly based on the needs of each party's own interests, focusing on the position of "for our own use". Most of the cooperation was carried out spontaneously by the people, and the official intervention of the three places was relatively small. The cooperation lacked long-term planning and overall view, and was mostly limited to the cooperation and exchange of a certain project, and lacked the institutional arrangement led by the government.[24] Looking forward to the future, the teacher education cooperation between Guangdong, Hong Kong and Macao should take the GBA construction as an opportunity, quickly integrate into the overall situation of national development, and move towards a win-win situation of complementary advantages, integrated development and inclusive progress. Under the framework of "one country, two systems", from "singing together" to "vibrating together", let the teacher education cooperation between Guangdong, Hong Kong and Macao develop into a community of common destiny, serving for GBA, long-term high "national identity" and the great rejuvenation of the Chinese nation.

\section{AUTHORS' CONTRIBUTIONS}

This paper is independently completed by Jiao Zeng.

\section{REFERENCES}

[1] Dove, L. A. Teachers and teacher education in developing countries: issues in planning, management and training. Croom Helm, 1986,pp.177.

[2] UNESCO.World Education Report 1998: Teachers and Teaching in a Changing World. Paris: UNESCO, 1998,PP.45.

[3] Dove, L. A. Teachers and teacher education in developing countries: issues in planning, management and training. Croom Helm, 1986,pp.181

[4] Zhou Hongyu \& Dan Zhaobin. The development and Enlightenment of Teacher Education in Hong Kong [J]. Research on higher normal education, 2000 (03),pp.7580.(in Chinese)
[5] Qiu Chao. The past, present and future of Teacher Education in China - an interview with Professor Gu Mingyuan [J]. Research on teacher education, 2014,26 (01),pp. 81-85((in Chinese)

[6] Ma zaoming. Collaborative innovation for 30 years: Retrospect and Prospect of teacher education cooperation between Guangdong, Hong Kong and Macao [J]. Journal of South China Normal University (SOCIAL SCIENCE EDITION), 2014 (06),pp. 62-67.(in Chinese)

[7] Pang Chuan, Lin Guangzhi, \& Hu Yating. Achievements and experience of higher education development in Macao since the return of China $[\mathrm{J}]$. Journal of South China Normal University: Social Science Edition, 2019 (5).(in Chinese)

[8] Li Shuying\&Li Gang. The historical evolution and future direction of Teacher Education in Macao [J]. On modern education, 2021 (01),pp.52-59.(in Chinese)

[9] Shi Yudan. A comparative perspective on the development of Teacher Education in Guangdong, Hong Kong and Macao [J]. Journal of Guangdong Normal University of technology, 2020,41 (01),pp.25-31.(in Chinese)

[10] Bei Lei, Gu Dingyi. Education in Hong Kong and Macao: continuity and change from a comparative perspective [M]. People's education press, 2006.(in Chinese)

[11] Outline of the 13th five year plan for national economic and social development of the People's Republic of China. [EB / OL] [2019$02-$

20].http://www.xinhuanet.com//politics/20161 h/2016-03/17/c_1118366322_14.html.(in Chinese)

[12] At present, there are 25 "Hong Kong and Macao children's classes" in 9 schools in Guangzhou[EB / OL] [2021-0322].http://news.cnr.cn/native/city/20210322/t2 0210322_525442904.html.(in Chinese)

[13] Zheng hang. National identity and patriotism education $[\mathrm{M}]$. Guangzhou: Sun Yat sen University Press, 2016,pp.63.(in Chinese)

[14] Chen Lijun. Analysis on the change of Chinese national consciousness of Hong Kong 
compatriots. United front studies,2014, 17 (2), pp.60-65.(in Chinese)

[15] Liu Zhengxian. Differentiation, integration and education of two kinds of national identity - focusing on the national identity of Hong Kong people $[\mathrm{J}]$. Journal of Guizhou Normal University (SOCIAL SCIENCE EDITION), 2014, 000 (005),pp.76-80.(in Chinese)

[16] Xing Lijun \& Xu Haibo. Thinking on the national identity and construction of Hong Kong Youth $[\mathrm{J}]$. Ningxia Social Sciences, 2014, 000 (004),pp. 150-154.((in Chinese)

[17] Zheng Hongtai, \& Yin Baoshan. (2014). A preliminary study of Hong Kong's local consciousness: a socio-economic and political perspective of identity. Hong Kong and Macao Studies (03), pp.67-79.(in Chinese)

[18] Lin Wei, \& Xiao Li. (2017). Changes and Countermeasures of Youth Political Participation in Macao. China Youth Studies, 000 (007), pp.48-54.(in Chinese)

[19] Hui Ming, Xu Haibo. Analysis on the dual identity of Hong Kong people [J]. Lingnan academic journal, 2016, 000 (002),pp. 5158.(in Chinese)

[20] Li Zijiang, Zhang Binxian. The construction of teacher qualification system in China: Problems and countermeasures [J]. Education research, 2008 (10),pp.43-46 .(in Chinese)

[21] Liu Xuanxuan. History, characteristics and Enlightenment of teacher qualification system in primary and secondary schools in Hong Kong [J]. Teacher education research, 2017,29 (03),pp.93-99.(in Chinese)

[22] LegCo. Law No. 9 / 2006 outline of non higher education system law[EB/OL][201701 -

8].http://bo.gov.mo/bo/i/2006/52/lei09_cn.asp. (in Chinese)

[23] Reply to proposal No. 2890 (Education No. 274) of the third session of the 13th National Committee of the Chinese people's Political Consultative Conference.[EB/OL][2020-1021].http://www.moe.gov.cn/jyb_xxgk/xxgk_jy ta/jyta_gjs/202011/t20201119_500826.html.(i n Chinese)

[24] Lu Xiaozhong. Thoughts on promoting educational cooperation and development in
Guangdong, Hong Kong and Macao [J]. China higher education research, 2019 (05),pp. 5457.(in Chinese) 